\title{
The combined heat and mass transit processes of water droplets in biofuel technologies
}

\section{Virginijus Ramanauskas}

$U A B$ Enerstena,

Raktažolių St. 21,

Kaunas LT-52181, Lithuania

E-mail:vramanauskas@enerstena.lt

\section{Monika Maziukienė,}

\section{Gintautas Miliauskas}

Kaunas University of Technology,

Studentu St. 56,

LT-51424 Kaunas, Lithuania

E-mail:monika.maziukiene@ktu.lt, gintautas.miliauskas@ktu.lt
The number of thermal technologies is based on water droplets heat and mass transfer processes. In this paper droplets heat transfer and phase transformations were modelled in the context of water spraying in humid flue gases application for biofuel combustion technologies. Droplets warming is defined when its surface instantaneous temperature is calculated according to an iterative numerical scheme, which is based on heat fluxes balance that flows in and from the droplet surface. The transfer processes interaction is taken into account. The influence of spraying water temperature, biofuel flue gases temperature and its humidity as well as droplets heating process impact on spraying water droplets transit phase transformation regimes were highlighted. Technological cases of water spraying in a biofuel furnace and heat recovery from removed flue gases were highlighted. In condensing economizers at recovered flue gases sprayed droplets heat transfer conditions are defined by their slipping factor in flue gases, while in the case of biofuel combustion in the furnace, droplets slipping and its surrounding radiation factors are equivalent.

Keywords: biofuel technologies, water spraying, droplets, phase transformation

\section{INTRODUCTION}

In order to conserve the fossil fuel and to reduce environmental pollution it is important to increase renewable energy component at energy production. For biofuel combustion technologies development it is important to recover heat from removed flue gasses, because huge amounts of water vapour latent heat quantities accumulate in flue gases during the process of humid biofuel combustion. The water spraying additionally irrigates air, which is supplied to the furnace and biofuel combustion process is controlled in the furnace. In this case spraying water droplets evaporate, therefore, it is important to define the temperatu- re and humidity of flue gases leaving the furnace. When using physical warmth of flue gases, they cool down, but still remain humid. The phase transformation heat from humid flue gases can be recovered when condensing the water vapour. Before release to the environment flue gases are directed to the condensing economizer. In the contact condensing economizer the water vapour condensates on sprayed water droplets and warms them up, while the heat of droplets warms thermofication water in plate heat exchangers. In recuperative type condensation economizer's technologies, the water in the flue gases is condensing when they flow through the tubes. In the upper part of the economizer the water is 
sprayed in order to irrigate biofuel flue gas flow, when they flow through tubes, and hydrodynamics of condensate film. Water droplets partly evaporate until entering the tubes. Therefore, it is important to evaluate flue gases irrigation and cooling. That is why for biofuel technologies it is important to know and define the water droplets heat and mass transfer. It has been investigated for over a century [1]. Due to a wide application of spraying technologies, the attention for droplet phase transformation is constantly growing [2]. It is important to know deeper the self-interaction of transfer processes, to define influencing factors and to evaluate its impact on phase transformations ongoing on droplets surface. Therefore, the emphasis of regularities of droplets surface temperature variation is the key to define sprayed water phase transformation and mass transfer in biofuel flue gases.

In this paper the water droplet warming and phase transformations in humid biofuel flue gas flow are modelled at different heat transfer boundary conditions. Special attention is given to condensation regime and variation of phase transformation regimes. The factors influencing the vapour flow on the droplet surface are defined.

\section{THE METHODOLOGY OF DROPLETS PHASE TRANSFORMATIONS NUMERICAL MODELLING}

The biofuel flue gases are defined by $T_{g, 0}$ temperature air and water vapour mixture flowing at speed $w_{g, 0}$, whose humidity is $\bar{p}_{v, 0}=p_{v, 0} / p$, when $p=10^{5}$ $\mathrm{Pa}$. The assumption $G_{l, 0} / G_{g, 0} \rightarrow 0$ is made, therefore $T_{g}(\tau) \equiv T_{g, 0} \bar{p}_{v}(\tau) \equiv \bar{p}_{v, 0}$ and $w_{g}(\tau) \equiv w_{g, 0^{\circ}}$ The convection heating for water droplets is defined by Reynolds $\mathrm{Re}_{0}$ number. The radiation is defined with parameter $\bar{T}_{s r}=T_{s r} / T_{g}$. In droplets convection heating " $c$ " case $\frac{s r}{s r}=0$. In the combined convection and radiation heating case " $c+r$ ", $\bar{T}_{s r}=1$. In conduction heating case " $k$ " $\mathrm{Re}_{0}=0$ and $\bar{T}_{s r}=0$. Droplets condensation, transit evaporation and equilibrium evaporation regimes are combined in the phase transformations $\tau \equiv 0-\tau_{k o}-\tau_{p f}-\tau_{f}$ cycle. Conditionally, external and internal droplets surface sides, when $R \equiv R^{+}$and $R \equiv R^{-}$, are separated. Droplet external and internal heating intensity is defined by components of convection and radiation:

$$
\begin{aligned}
& q_{\Sigma}\left(\tau, R^{+}\right)=q_{c}\left(\tau, R^{+}\right)+q_{r}\left(\tau, R^{+}\right) \\
& q_{\Sigma}\left(\tau, R^{-}\right)=q_{c}\left(\tau, R^{-}\right)+q_{r}\left(\tau, R^{-}\right) .
\end{aligned}
$$

The convection heat flux supplied for a droplet is described by the Newton's law, while the convection heat flux in a droplet is described according to a modified Fourier law of heat conduction:

$$
\begin{aligned}
& q_{c}\left(\tau, R^{+}\right)=\lambda_{v g}(\tau) \frac{T_{g}-T_{R}(\tau)}{2 R(\tau)} \cdot N u_{f}(\tau) ; \\
& q_{c}\left(\tau, R^{-}\right)=-\left.\lambda_{l}(\tau) \frac{\partial T_{l, " k+r},(\tau, r)}{\partial r}\right|_{r=R} \cdot k_{c}^{-}(\tau) .
\end{aligned}
$$

The condition $T_{R}(\tau)<T_{d}$ is provided, therefore external heat flux components $q_{c}^{+}$and $q_{r}^{+}$will be positive sign sizes, of which vectors are directed into the droplet. The radiation $q_{c}^{-}$flux spreads toward the centre of the droplet, while $q_{c}^{-}$flux direction is defined by temperature field gradient in the droplet. The radiation flux absorption in the droplet and the observed optical effects of light beam reflection and refraction, when crossing the contact surface of water and flue gases, are defined by a complex spectral index of refraction $\bar{n}_{\omega}=n_{\omega}-i k_{\omega}$, where $n_{\omega}$ and $k_{\omega}$ components are finite sizes [3], therefore $q_{c}^{-} @ q_{c}^{+}=q_{r}$. The radiation flux is calculated according to the spectral radiation model in the droplet [4]. The droplet unsteady temperature field gradient is defined for combined heat spread by conduction and radiation case [4], while the forced water circulation influence is evaluated by an effective heat conductivity parameter in a slipping droplet [5]. Water phase transformation heat and vapour flux on the droplet surface defines the phase transformation heat flux. The phase transformation heat flux density depends on vapour flux density [6]:

$$
\begin{gathered}
q_{f}(\tau)=L(\tau) \cdot m_{g}(\tau) \equiv L(\tau) \frac{M_{v}}{R_{\mu}} \frac{D_{v g}(\tau)}{T_{v g, R}(\tau) R(\tau)} \\
\left\{p_{v, R}(\tau)-p_{v, g}+\frac{\mathrm{M}_{v}}{\mathrm{M}_{g}}\left[p \ln \frac{p-p_{v, g}}{p-p_{v, R}(\tau)}-p_{v, R}(\tau)+p_{v, g}\right]\right\}
\end{gathered}
$$

In condensation regime the vapour flux is negative sign size, while it is positive in evaporation regime. The vector direction variation of vapour flux on the droplet surface in expression (3) provides the Stefan's hydrodynamic flow impact for 
two phase flow, which is evaluated by Stefan's logarithm. The model of heat fluxes (1-3) enables to supply the universal interpretation of droplet energy state in the entire, on the droplet surface ongoing, phase transformation regimes cycle:

$$
q_{r}\left(\tau, R^{-}\right)-q_{c}\left(\tau, R^{-}\right)=q_{\Sigma}\left(\tau, R^{+}\right)-q_{f}\left(\tau, R^{+}\right) .
$$

The expression (4) describes the interconnection of heat fluxes on the droplet surface, and that defines droplet surface temperature $T_{R}(\tau)$ function: the droplet surface instantaneous temperature at freely selected $\tau_{i}$ time must ensure the fulfilment of the requirement of heat fluxes flowing in and from the surface. Therefore, to develop the expression (4) numerical research scheme, the finite number of control time $\tau_{i>1}=\tau_{i-1}+\Delta \tau$ moments is foreseen. $\Delta \tau=\tau_{f} /(I-1)$, when $I=201$. The droplet diameter changes in the phase transformation cycle. Therefore, in the numerical scheme the internal layers of droplets are grid in aspect of radial $\eta=r / R_{i}$ coordinate $\eta_{j>1}=\eta_{j-1}+\Delta \eta$, when $\Delta \eta=1 /(J-1)$ and $J=41$. Starting with the $\tau_{i=2}$ time moment the iterative cycle is organized according to the fastest descent method to define the droplet surface instantaneous $T_{R, i}$ temperature. For the final IT iteration the requirement is that the selected $T_{R, i, i t=I T}$ temperature according to the calculated heat fluxes on droplet surface will ensure the fulfilment of the requirement (4) with the accuracy of five one hundredths of one percent. Values $T_{R, i}=T_{R, i, i t=I T}$ are assigned for instantaneous droplet surface temperatures. Heat flux densities on the droplet surface are calculated according to numerical equations (28-40) provided in [7].

\section{RESULTS}

In biofuel combustion technologies water droplets heat transfer and phase transformations proceed in a wide boundary conditions range. Flue gas humidity is defined by water vapour volume part $\bar{p}_{g} \equiv 0-0.3$, when $T_{g}=400-1300 \mathrm{~K}$. $T_{0}=278 \mathrm{~K}$ temperature water is sprayed. Droplets temperature variation in phase transformation regime depends on droplet heating case and dispersity. The droplet surface temperature $T_{R}(\tau)$ distribution is individual for different dispersity droplets (Fig. 1a). At $1300 \mathrm{~K}$ temperature and $\bar{p}_{v}=0.15$ humidity of the biofuel flue gases, small water droplets warm up very fast from initial $278 \mathrm{~K}$ temperature up to the dew point $338.14 \mathrm{~K}$ temperature, while larger droplets warming time is significantly longer: in " $c$ " heat transfer case $\tau_{k 0, \text {, }{ }^{\circ} \text { " }} s \equiv 0.0028,0.011$, and 0.069 , while in " $c+r$ " case $\tau_{k o, " c+r,} s \equiv 0.0025 ; 0.0089 ; 0.04$, when droplet radius is 50,150 , and 250 micrometres, respectively.

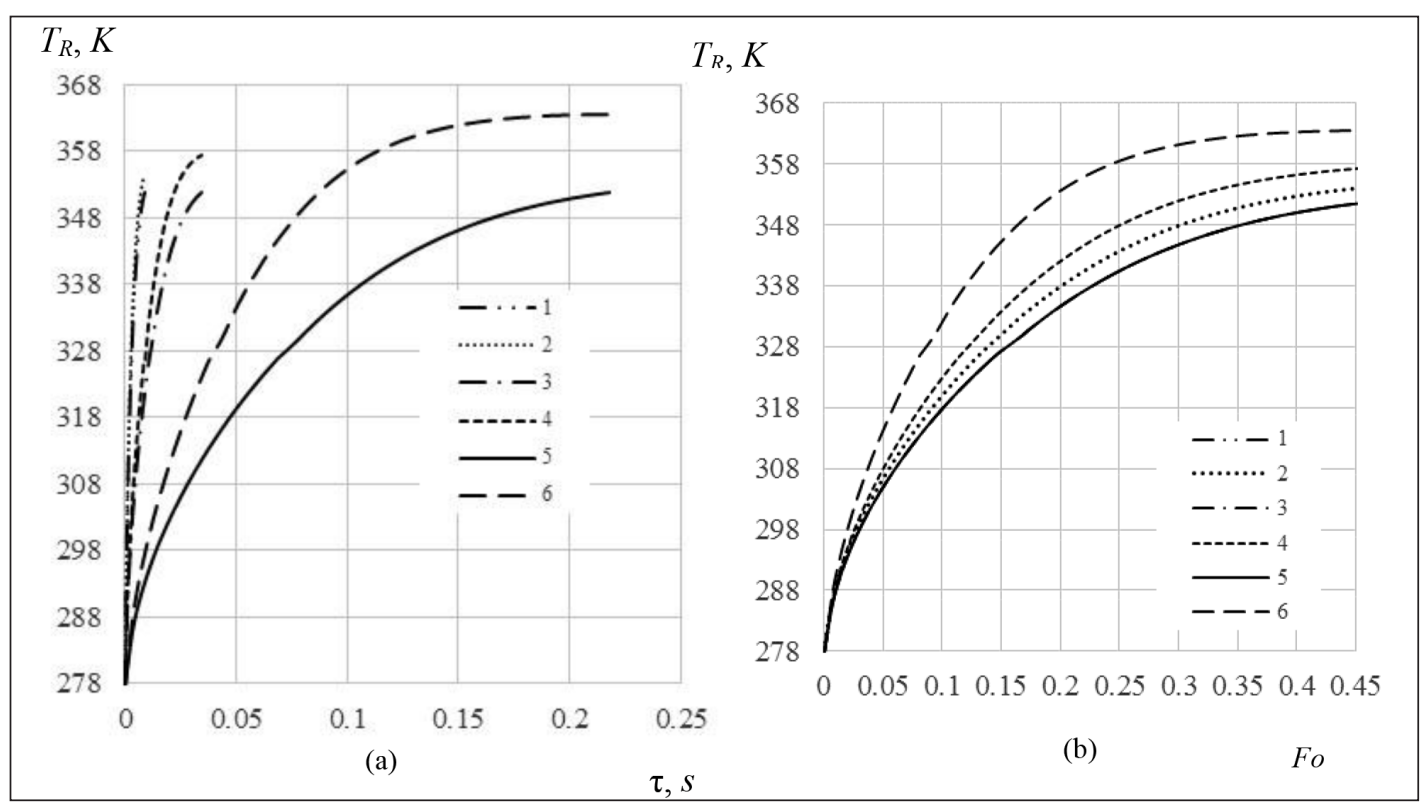

Fig. 1. The impact of water spraying dispersity on the droplet surface temperature (a) $T_{R}(\tau)$ and (b) $T_{R}(F o)$ functions. Droplet heating case $(1,3,5){ }^{\prime \prime} c^{\prime \prime},(2,4,6){ }^{\prime \prime} c+r^{\prime \prime} ; R_{0} \cdot 10^{6}, \mathrm{~m}:(1,2) 50,(3,4) 100,(5,6) 250 ; \mathrm{Re}_{0}=50 ; \bar{p}_{v}=0.15 ; T_{g}=1300 \mathrm{~K}$ 
A more detailed results analysis justified the time scale, expressed by Fourier $F o=\tau \cdot a_{0} / \mathrm{R}_{0}^{2}$ number, importance for generalization of the droplets phase transformation cycle. In droplets " $c$ " heating case the calculated condensation regime duration $\mathrm{Fo}_{k o}=0.15$ is independent from droplets dispersity, therefore functional $T_{R, " c "}(F o)$ graph is universal for all droplets (Fig. 1b; curves 1, 3,5).

The flue gases energy impact on sprayed water droplets is defined by heat flux $q_{\Sigma}^{+}$density taking into account the radiation and convection heat transfer components that are sensitive to flue gases temperature and droplets dispersity (Fig. 2).

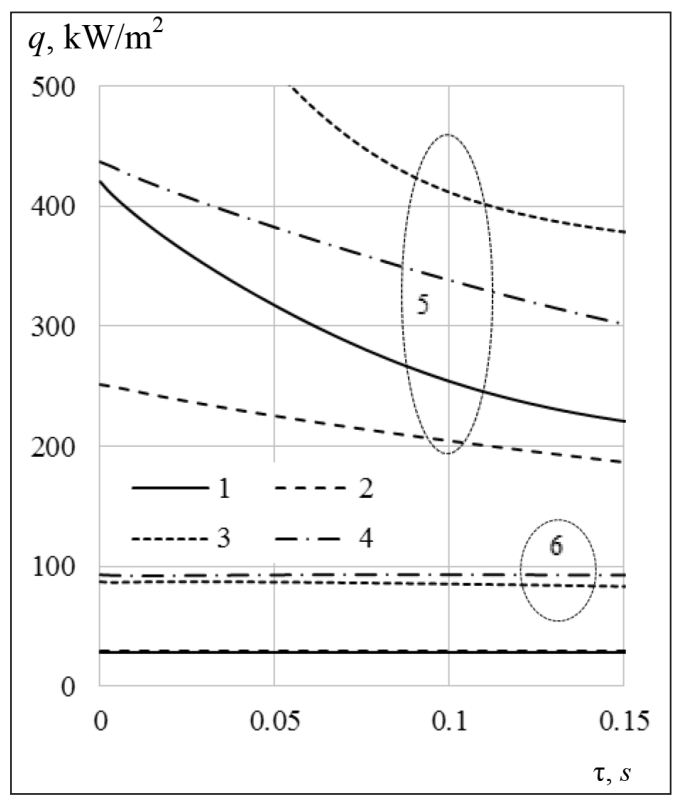

Fig. 2. The impact of flue gas temperature and droplets dispersity of external heat flux components. $\bar{p}_{v}=0.15$; $\mathrm{Re}_{0}=35 ; T_{g^{\prime}} \mathrm{K}:(1,2) 900,(3,4) 1200 ; R_{0} \cdot 10^{-6}, \mathrm{m:}:(1,3)$ $150,(2,4) 250 ; q:(5) q_{c}^{+},(6) q_{r}$

When $T_{g}=900 \mathrm{~K}$, then $q_{c, 0}^{+}, \mathrm{kW} / \mathrm{m}^{2}$ is 420.76 , and 251.3, while $q_{r, 0}, \mathrm{~kW} / \mathrm{m}^{2}$ is 28.83 and 30.01 , when $R$ is 150 and 250 micrometres, respectively. When $T_{g}=1200 \mathrm{~K}$, then $q_{c, 0}{ }^{+}, \mathrm{kW} / \mathrm{m}^{2}$ is 730.27 and 436.77 , while $q_{r, 0}, \mathrm{~kW} / \mathrm{m}^{2}$ is 86.91 and 93.08 , when $R$ is 150 and 250 micrometres, respectively. In condensation regime, droplets warm up rapidly (Fig. 1), while its diameter changes relatively little. Therefore, the decrease of convection heat flux density in the initial intensive droplet heating stage is caused by flue gas temperature and droplet temperature difference $\Delta T=T_{g}-T_{R}$ variation. The absorbed radiation flow in water depends on droplets size while the local $q_{r, n}$ density is distributed individually within different size droplets (Fig. 3). Strong radiation flux nonlinearity in droplets is defined by light reflection spectral effects on the droplets surface, which also depends from water temperature [3]. Therefore the droplet surface temperature $T_{R,{ }^{\prime \prime}+r^{\prime \prime}}(F o)$ function graph remains sensitive regarding droplets dispersity in " $c+r$ " case (Fig. 1b;

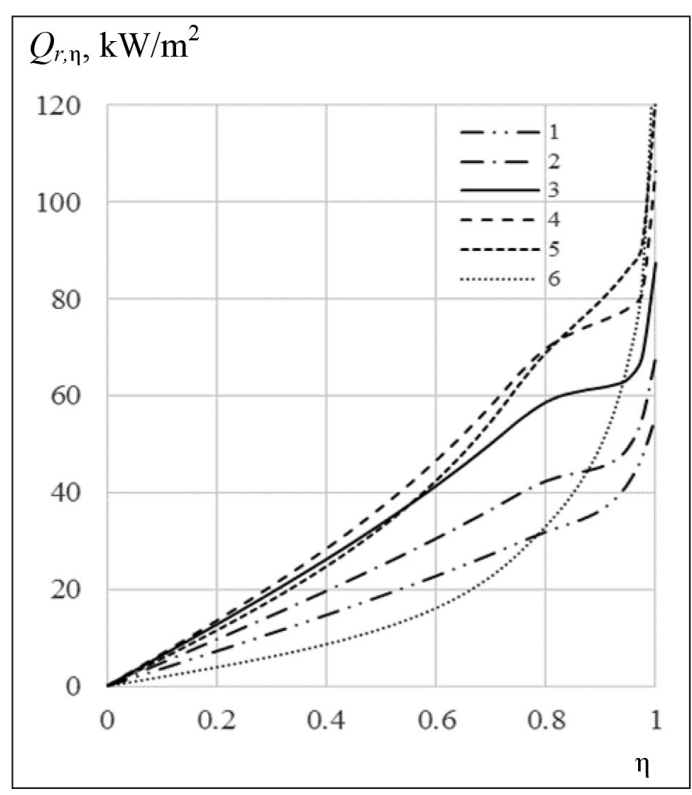

Fig. 3. The impact of droplets dispersity for local radiation flux inside droplet. $T_{s r}=1300 \mathrm{~K} ; R \cdot 10^{-6}, \mathrm{~m}(1) 15,(2) 25$, (3) 50, (4) 100, (5) 200, (6) 1000

curves $2,4,6)$. At the case defined by boundary conditions parameters $R e_{0}, T_{0}, \bar{q}_{v}$ and $T_{g}$, the noticed universality of droplets surface function $T_{R, "{ }^{\prime \prime} \text { ( }}(F o)$ graph is valid for all thermal parameters that are related to droplet unsteady temperature field, e.g. $P_{T^{\prime \prime c} c^{\prime \prime}}(F o)$ functions. The droplet parameter $P_{q, " c "}(F o)$ function distributions, as well as $P_{q, " c t r r^{\prime \prime}}(F o)$ function distributions are not universal in aspect of droplets dispersity. However, the provided function graphs are universal by the aspect of droplets dispersity in dimensionless $\bar{P}_{q, c^{\prime \prime}}(F o) \equiv P_{q, " c "}(F o) / P_{q, 0}$ form (Fig. 4; curves $1,3,5)$. In the combined " $c+r$ " heat transfer case the $\bar{P}_{q, " c+r "}(F o)$ function graphs are individual for a different dispersity level of droplets (Fig. 4; curves $2,4,6$ ). 


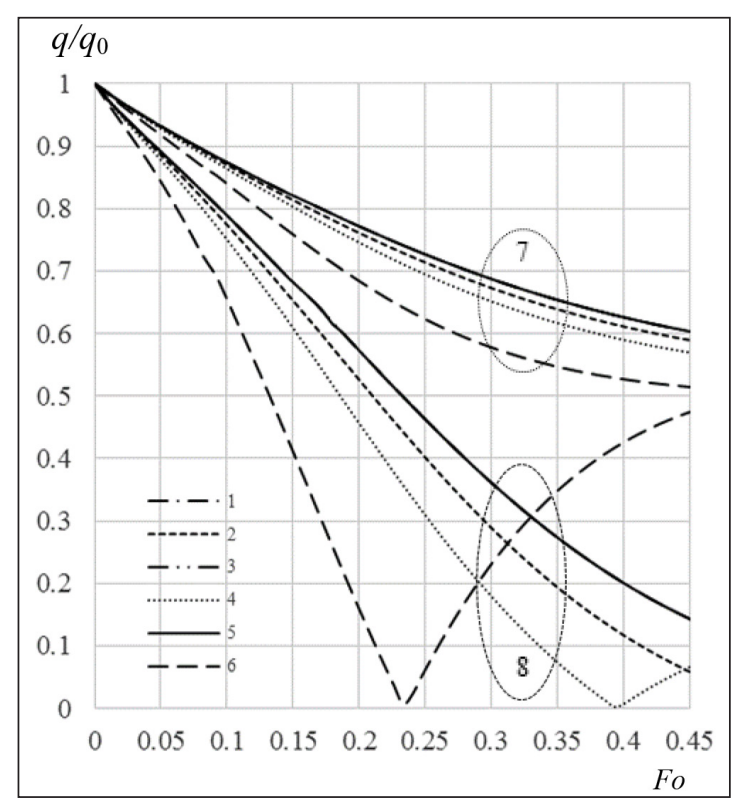

Fig. 4. The impact of droplets dispersity on convection heat fluxes $q_{c}^{+}(F 0) / q_{c, 0}^{+}$and $q_{c}^{-}(F o) / q_{c, 0}^{-}$function, which are indicated by curves (7) and (8), respectively. Marking is the same as in Fig. 1

The discussed energy parameters $\bar{p}_{q}(F o)$ functions regularities are also valid for droplet phase transformation parameters $\bar{p}_{f}(F o)$ functions. This is confirmed by vapour flux $\bar{g}_{v}$ (Fo) function graphs - the main phase transformation parameter (Fig. 5 ; curves 1, 3, 5). In the combined " $c+r$ " heat

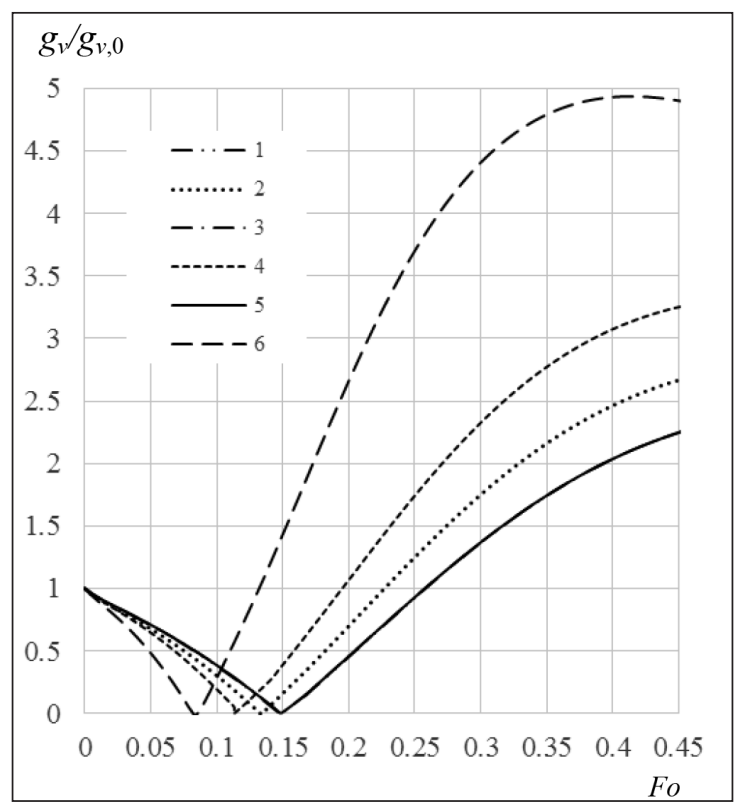

Fig. 5. The impact of droplets dispersity on vapour flux $g_{v}(F o) / g_{v, 0}$ functions. Boundary conditions the same as in Fig. 1 transfer case, the specific function $\bar{P}_{{ }^{\prime c}+r^{\prime}, R_{0}}(F o)$ graph inclination regarding function ${ }^{c+P^{p}, R_{0}}{ }{ }^{\prime}{ }^{\prime \prime}(F o)$ universal graph will define the radiation impact to heat and mass transfer parameter for the droplet of specific dispersity. This method is applied to evaluate the influence of boundary conditions. According to the generalized modelling results the main defining parameters of droplets heat transfer conditions are: flue gas temperature and humidity, sprayed water temperature, droplets dispersity and initial slipping in flue gases. On the surface, of cold water droplets which are sprayed into biofuel flue gases of high temperature and average humidity, the initial calculated density of condensing water vapour flux is $0.204,0.102$, and $0.0408\left(\mathrm{~kg} / \mathrm{m}^{2} \mathrm{~s}\right)$, when droplet diameter is 100,200 , and 500 micrometres, respectively. When droplet warms intensively in condensation regime the vapour flux on the droplet surface decreases to zero, while during evaporation regime it rapidly increases (Fig. 5).

In transit evaporation regime, compared with the initial condensing vapour flux, the vapour flux on the droplet surface increases more than two times in " $c$ " heat transfer case, while in combined " $c+r$ " heat transfer case the observed vapour flux variation is more significant and for droplets of big size can reach even five hundred percentages (Fig. 5). Therefore, for further analysis the radiation impact is evaluated for large 500 micrometres diameter droplets, providing that this case will define maximum radiation impact on phase transformations of water droplets sprayed in biofuel flue gases. When flue gas temperature decreases, the duration of condensation phase transformation regime on droplet surface increases and radiation impact reduces, $\mathrm{Fo}_{k o,{ }^{\prime \prime c} c^{\prime}}$ is $0.754,0.346$, and 0.18 , while $F o_{k o, " c+r, R_{0}=250}$ is $0.686,0.257$, and 0.107 when $T_{g}, \mathrm{~K}$ is 600,900 , and 1200 , respectively. Biofuel flue gas of relatively low $T_{g}<600 \mathrm{~K}$ temperature flows into the condensing economizer, therefore the heating process of water droplets sprayed in flue gases is defined by convection heat transfer. The duration of condensation phase transformation regime depends on flue gas humidity: $\mathrm{Fo}_{\mathrm{koo}}$ "c" at modelled cases is $0,0.24,0.544,0.812,1.001$, and 1.113 when $\bar{p}_{g}$ is $0,0.02,0.04,0.08,0.15$, and 0.3 , respectively. In transit phase transformation regime, the vapour flux, compared with initial, in dry flue gases increases more than 12 times, while in average and high humidity flue gases the initial 
value does not change. Droplets convection heating is defined by droplets slipping development in water spraying process in flue gases, which is evaluated by initial Reynolds $\mathrm{Re}_{0}$ number. Friction forces are increasing on the surface of slipping droplets in flue gases. These forces evoke water flow on the surface and therefore the local whirls forms, which causes the convection heat transfer from droplet surface to internal layers. The warming of droplet central layers is accelerated due to water circulation, while for surface layers is opposite [7]. Therefore, the surface of intensively slipping droplet warms longer up to the dew point and the duration of condensation phase transformation regime is increasing (Fig. 6): $F o_{k o, " c "}$ for simulated cases are $0.79,0.913,1.023$, and 1.082 , when $\operatorname{Re}_{0}$ is 10,20 , 40 , and 100 , respectively. When condensation regime duration increases, more water vapour is condensed out from flue gases and heat recovery from the removed biofuel flue gases is more effective.

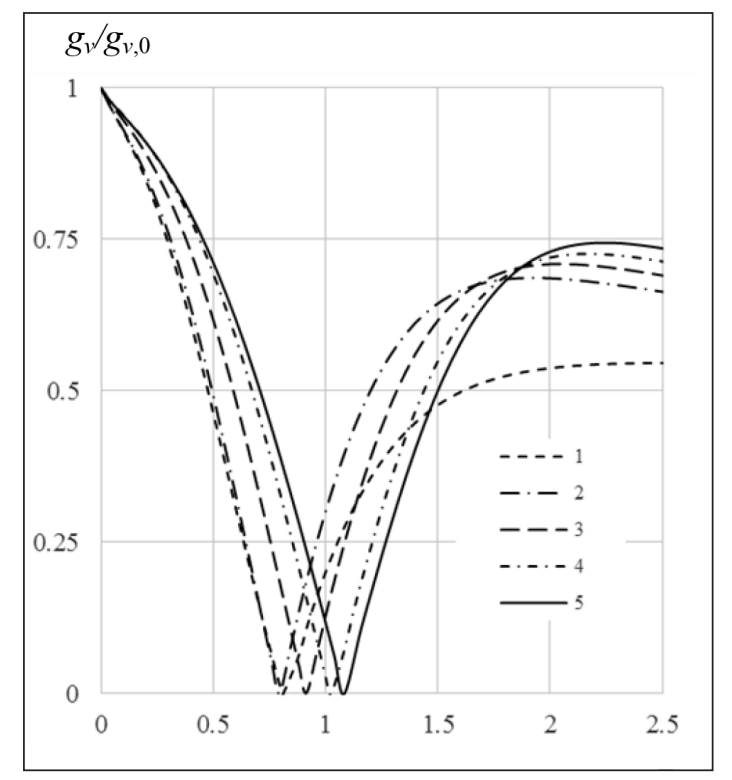

Fig. 6. The impact of droplets slipping on vapour flux in " $c$ " heat transfer case. $T_{g}=500 \mathrm{~K} ; \bar{p}_{v}=0.15$; Re: (1) $0,(2) 10$, (3) 20, (4) 40, (5) $100 ; R_{0}=50 \cdot 10^{-6} \mathrm{~m} ;\left|m_{v, 0}\right|=0.077 \mathrm{~kg} /\left(\mathrm{m}^{2} \mathrm{~s}\right)$

The described phase transformation metodics reliability is confirmed when the calculated vapour flux on the droplet surface is compared with equilibrium evaporation rate at combined " $k+r$ " heating case defined in [8] (Fig. 7). The experiment [8] conditions were replaced when droplet diameter stability was provided.

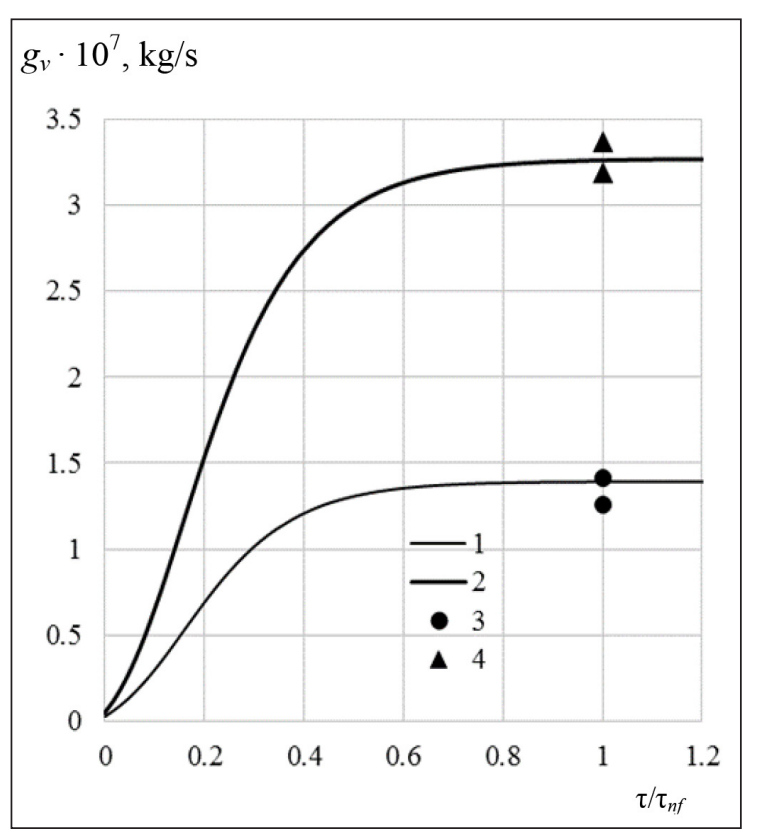

Fig. 7. The vapour flux on the droplet surface in combined " $k+r$ " heating case $T_{s r} \equiv T_{g}=1043 \mathrm{~K} ; \bar{p}_{v}=0 ; R(\tau) \cdot 10^{-6}, \mathrm{~m}:(1,3) 505$, $(2,4) 780$; Lines are numerical simulation; dots are experimental values [8]

\section{CONCLUSIONS}

The factors defining the phase transformation cycle of water droplets sprayed in biofuel flue gases are: flue gases temperature and humidity, water temperature and droplets dispersity, as well its heating process. The defining factor of heat transfer is droplet slipping intensity when heat is recovered from relatively low temperature flue gases. When flue gases temperature rises, the radiation impact increases and radiation as well as droplet slipping factors are equivalent in high temperature flue gases. Droplets heat and mass transfer parameters function $\bar{P}(F o)$ distributions are universal in aspect of droplets dispersity in " $c$ " heat transfer case. This allows to optimize the numerical modelling of water droplets heat and mass transfer when droplet is sprayed in biofuel flue gases. It is enough to simulate the phase transformation cycle of freely chosen diameter and according to its results it is possible to define the universal functions $\bar{P}_{{ }^{\prime c} c^{\prime}}(F o)$ for the desirable droplets dispersity. These functions can be easily transformed into individual functions $P(\tau)$ based on individual parameters $P_{0}$ and $a_{0} / R_{0}^{2}$. At the combined droplet heating case, the phase transformation cycle will be individual for each droplet. 


\section{ABBREVIATIONS}

$a$ - thermal diffusivity, $\mathrm{m}^{2} / \mathrm{s} ; D$ - mass diffusivity, $\mathrm{m}^{2} / \mathrm{s} ; F o$ - Fourier number; $G$ - mass flux rate, $\mathrm{kg} / \mathrm{s}$; $k_{c}$ - effective conductivity parameter; $k_{\omega}$ - spectral coefficient of absorption, $\mathrm{m}^{-1} ; L$ - latent heat of evaporation, J/kg; $m$ - vapour mass flux, $\mathrm{kg} /$ $\left(\mathrm{m}^{2} \mathrm{~s}\right) ; M-$ mass, $\mathrm{kg} ; \mu$ - molecular mass, $\mathrm{kg} / \mathrm{mol}$; $n_{\omega}$ - spectral index of refraction; $\mathrm{Nu}$ - Nusselt number; $p$ - pressure, $\mathrm{Pa} ; P$ - symbol of free parameter in heat-mass transfer; $R e$ - Reynolds number; $q$ - heat flux, $\mathrm{W} / \mathrm{m}^{2} ; r$ - radial coordinate, $\mathrm{m} ; R_{\mu}$ - universal gas constant $\mathrm{J} /(\mathrm{kgl} \mathrm{K}) ; T$ - temperature, $\mathrm{K}$; $\eta$ - non-dimensional radial coordinate; $\lambda$ - thermal conductivity, $\mathrm{W} /(\mathrm{m} \mathrm{K}) ; \rho$ - density, $\mathrm{kg} / \mathrm{m}^{3} ; \tau$ - time; $w$ - velocity, $\mathrm{m} / \mathrm{s}$.

Subscripts: $C$ - droplet centre; $c$ - convection; $c+r$-combined heating by convection and radiation; $f$ - phase change; $g$ - gas; $i$ - time index in a digital scheme; it - number of iteration; $I$ - index of control time; $j$ - index of radial coordinate; $J$ - index of droplet surface; $k o$ - condensation; $k$ - conduction; $k+r$-combined heating case by conduction and radiation; $l$ - liquid; $m$ - mass average; $p f$ - transit phase transformation regime; $r$ - radiation; $r t$ - dew point; $R$ - droplet surface; $s r$ - radiation source; $v$ - vapour; $v g$ - gas-vapour mixture; $\omega$ - spectral; $\Sigma$ - total; 0 - initial state; $\infty$ - far from droplet; + - external side of droplet surface; - - internal side of droplet surface.

Received 1 March 2017 Accepted 15 May 2017

\section{References}

1. Fuks N. A. Evaporation and Droplet Growth in Gaseous Media. London: Pergamon Press, 1959.

2. Sazhin S. S. Droplets and Sprays. London: Springer, 2014.

3. Hale G. M., Querry M. R., Rusk A. N., Williams D. Influence of temperature on the spectrum water. Journal of the Optical Society of America. 1972. Vol. 62. P. 1103-1108.

4. Miliauskas G. Regularities of unsteady radiative-conductive heat transfer in evaporating liquid droplets. International Journal of Heat and Mass Transfer. 2001. Vol. 44. P. 785-798.

5. Abramzon B., Sirignano W. A. Droplet vaporization model for spray combustion calculations.
International Journal of Heat and Mass Transfer. 1989. Vol. 32. P. 1605-1618.

6. Kuzikovskij A. V. Dynamics of spherical particle powerful optical field. Izv. VUZ: Fizika. 1970. Vol. 5. P. 89-94.

7. Miliauskas G., Maziukiene M., Ramanauskas V. Peculiarities of the transit phase transformation regime for water droplets that are slipping in humid gas. International Journal of Heat and Mass Transfer. 2016. Vol. 102. P. 302-314.

8. Ivanov V. M., Smirnova E. V. Experimental research of liquid droplets evaporation velocity in non-moving high temperature environment. Tr. IGI. 1962. Vol. 19. P. 46-58.

Virginijus Ramanauskas, Monika Maziukienè, Gintautas Miliauskas

\section{SUDĖTINIAI VANDENS LAŠELIŲ PEREINAMIEJI ŠILUMOKAITOS IR FAZINIŲ VIRSMŲ PROCESAI BIOKURO TECHNOLOGIJOSE}

\section{Santrauka}

Vandens lašelių šilumos ir masès mainų procesais grindžiama daugelis terminių technologijų. Darbe skaitiškai sumodeliuota lašelių šilumokaita ir faziniai virsmai drègnuose dūmuose pagal vandens išpurškimo pritaikymo biokuro deginimo technologijas. Lašelių šilimas apibrèžtas jų paviršiaus momentinę temperatūrą apskaičiuojant pagal iteracinę skaitinę schemą, kuri grịsta prie lašelio paviršiaus pritekančių ir nutekančių šilumos srautų balansu. Atsižvelgta i pernašos procesų tarpusavio sąveiką. Išryškinta išpurškiamo vandens temperatūros, biokuro dūmų temperatūros ir jų drègnumo bei lašelių šildymo proceso ịtaka išpurkšto vandens lašelių pereinamųjų fazinių virsmų režimui. Akcentuoti vandens išpurškimo biokuro kūrykloje ir ịpurškimo ị šalinamus dūmus šilumos iš jų utilizavimo technologijos atvejai. Dūmų šilumos utilizavimo kondensaciniuose ekonomaizeriuose lašelių šilumokaitos sąlygas apibrèžia jų slydimo dūmuose veiksnys, o biokuro deginimo kūrykloje atveju lašelių slydimo ir apsupties spinduliavimo veiksniai yra lygiaverčiai.

Raktažodžiai: biokuro technologijos, vandens išpurškimas, lašeliai, faziniai virsmai 